\title{
New data (U-Pb, K-Ar) on the geochronology of the alkaline-carbonatitic association of Fuerteventura, Canary Islands, Spain
}

\author{
Mercedes Muñoz ${ }^{\mathrm{a}, *}$, Juana Sagredo ${ }^{\mathrm{b}}$, Cristina de Ignacio ${ }^{\mathrm{c}}$, \\ Javier Fernández-Suárez ${ }^{\mathrm{a}}$, Teresa E. Jeffries ${ }^{\mathrm{d}}$ \\ ${ }^{a}$ Departamento de Petrología y Geoquímica, Fac. CC. Geológicas, Universidad Complutense, 28040 Madrid, Spain \\ ${ }^{\mathrm{b}}$ Instituto de Geología Económica, CSIC, Universidad Complutense, 28040 Madrid, Spain \\ `Departamento de Matemáticas, Física aplicada y Ciencias de la Naturaleza, Universidad Rey Juan Carlos, C/Tulipán s/n, 28933, \\ Móstoles, Madrid, Spain \\ ${ }^{\mathrm{d}}$ Department of Mineralogy, The Natural History Museum, London SW7 5BD, United Kingdom
}

\begin{abstract}
Zircons from a nepheline-syenite of the Fuerteventura Basal Complex were dated by Laser Ablation Inductively Coupled Plasma Mass Spectrometry (LA-ICP-MS). The age obtained from a total of $21 \mathrm{U}-\mathrm{Th}-\mathrm{Pb}$ analyses is $25.4 \mathrm{~F} 0.3 \mathrm{Ma}(2 \mathrm{r})$ indicating a late Oligocene-early Miocene crystallization. This age is consistent with new K-Ar ages on nepheline-syenites and pyroxenites, and contradicts previously published ${ }^{39} \mathrm{Ar}-{ }^{40} \mathrm{Ar}$ (feldspar) ages that were interpreted to represent a late Cretaceousearly Paleocene, pyroxenitic-syenitic magmatic episode. These new geochronological data are consistent with both field observations and most of the previously published ages on alkaline silicate rocks and associated carbonatites of Fuerteventura. Therefore, they strongly support the existence of a single, late Oligocene-early Miocene event of alkaline-carbonatitic magmatism in the Basal Complex of Fuerteventura, taking place at approximately $25 \mathrm{Ma}$ and comprising: alkaline-pyroxenites, melteigites-ijolites, nepheline-syenites and carbonatites, as well as their volcanic equivalents and associated dykes.

These new data provide an estimate for the length of time that it took the island to grow, thus eliminating one of the major problems in explaining its development by a hot-spot model.
\end{abstract}

Keywords: Canary Islands; Fuerteventura; Syenite; LA-ICP-MS; Zircon

\footnotetext{
* Corresponding author. Fax: +34 915442535.

E-mail addresses: fuertm@geo.ucm.es (M. Muñoz), sagredo@geo.ucm.es (J. Sagredo), cignacio@escet.urjc.es (C. de Ignacio), jfsuarez@geo.ucm.es (J. Fernández-Suárez),
}

\section{Introduction}

The Canary archipelago is peculiar in that intrusive rocks cropping out in three of its islands (Fuerteven- 
tura, La Gomera and La Palma) represent the roots of different volcanic edifices, providing a unique opportunity to study the process of growth and evolution of these islands. The intrusive rocks belong to the socalled Basal Complexes in each island, among which the Basal Complex of Fuerteventura is the oldest. One of the controversial issues concerning the evolution of Fuerteventura is the age of the onset of the magmatism with which the growth of the island started and hence the onset of magmatism in the Canary archipelago. According to some authors this magmatism would have begun by the late Cretaceous-early $\mathrm{Pa}-$ leocene (Robertson and Stillman, 1979; Le Bas et al., 1986; Balogh et al., 1999), involving an approximately 65 Ma span of igneous activity in the island of Fuerteventura. In turn, for other authors (Fúster et al., 1980; Cantagrel et al., 1993; Sagredo et al., 1996) the activity would have started during the Oligocene and therefore, the development of the island would have taken place over the last 35-30 Ma. These different ages were obtained in rocks belonging to the oldest intrusive episode of the Basal Complex of Fuerteventura, which comprises alkaline ultramafic rocks to nepheline-syenites and carbonatites, and gave rise to a discrepancy concerning the number of episodes of carbonatites and associated alkaline silicate rocks in the island. With the purpose of solving this discrepancy about the age of the alkaline-carbonatitic magmatism in Fuerteventura, we review previously published ages on the Basal Complex alkaline silicate rocks, carbonatites and associated dykes and present: Laser Ablation Inductively Coupled Plasma Mass Spectrometry (LA-ICP-MS) U-Pb ages of zircon from a nepheline-syenite as well as $\mathrm{K}-\mathrm{Ar}$ ages of a nepheline-syenite and two clinopyroxenites from the central-western sector of the Basal Complex, where the oldest ages (63-64 Ma) have been reported for nepheline-syenites (Balogh et al., 1999). The obtained ages, which are discussed in the context of geological relationships, largely contribute to clarify the above mentioned discrepancy and have important implications on the growth and development of the island.

\section{Geological setting}

The Canary archipelago is composed of seven islands, of which the easternmost, Lanzarote and
Fuerteventura lay out in a NE-SW trend, roughly parallel to the African continental margin, and at approximately $100 \mathrm{~km}$ offshore the Moroccan coast. In the island of Fuerteventura, three main units can be differentiated, from older to younger: the Basal Complex, the Miocene volcanic edifices, and the PlioceneQuaternary volcanics (Fig. 1). The Basal Complex, exposed in the western part of the island, is composed of: oceanic sediments of Mesozoic and Cenozoic age, volcanic materials, and several kinds of intrusions, as well as a dense dyke swarm crosscutting most of these materials. The different kinds of intrusions, which are related to different kinds of dykes and volcanics, can be grouped in the following episodes (Muñoz et al., 2003): 1) a submarine volcanic episode (EVS) that represents the submerged growth stage of the island; 2) an alkaline-carbonatitic event, EM1, comprising alkaline pyroxenites, melteigites-ijolites, nephelinesyenites and carbonatites and hydromagmatic volcanics of similar composition. This episode represents the transition between the submarine and subaerial growth stages of the island; 3) a mafic-ultramafic, EM2 event of transitional composition, comprising pyroxenites and gabbros and equivalent volcanics; 4) a third magmatic event, EM3, represented by the alkaline gabbros and syenites of the Vega de Río Palmas Complex and; 5) an EM4 event, represented by the volcanic-subvolcanic edifice of Betancuria. The volcanic rocks belonging to the EM2, EM3 and EM4 events represent the subaerial growth stage of the island.

The EM1, alkaline-carbonatitic intrusive rocks crop out in an almost continuous, NE-SW fringe in the western part of the island, comprising two main sectors: the northwestern, Montaña Blanca-Esquinzo sector, and the central-western, Ajui-Solapa sector (Fig. 1), this work being mainly focused on the latter. These alkaline-carbonatitic rocks are intrusive in the submarine volcanic episode (EVS) and are considered by the authors as the roots of dismantled volcanic edifices of equivalent composition (Muñ oz et al., 2002). In turn, the EM1 alkaline-carbonatitic rocks are intruded by the EM2, mafic-ultramafic rocks, mainly represented by the Pájara pluton in the AjuiSolapa sector. This pluton, emplaced along transtensive, dextral shear zones (Muñoz et al., 1997), produces a contact metamorphic aureole in the EM1 rocks and dykes. 


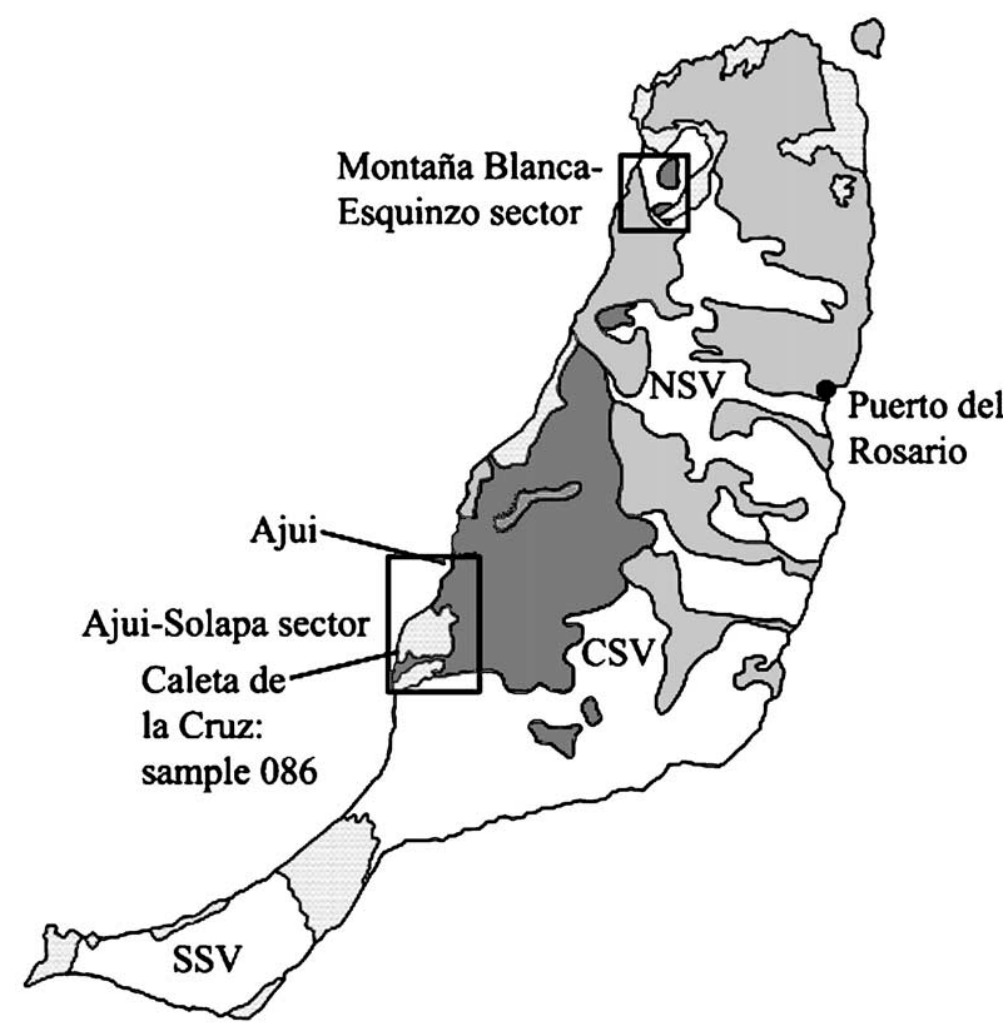

Fig. 1. Main geological units of Fuerteventura: dark grey=Basal Complex; white (NSV, CSV, SSV=Miocene Northern, Central and Southern Shield Volcanics respectively); light grey=Pliocene and Quaternary volcanics; light grey, dotted=Quaternary sediments.

At Caleta de la Cruz, located in the Ajui-Solapa sector (Fig. 1), where the EM1 carbonatites and alkaline silicate rocks occur, some key field relationships can be observed. The alkaline pyroxenites at this outcrop comprise amphibole-, micaceous (sometimes glimmeritic) and perovskite-bearing types, that in some places grade into melteigite-ijolite. These ultramafic and mafic rocks are crosscut by veins, dykes and irregular masses of nepheline-syenite and carbonatite. All this set is affected by WNW-ESE shear zones (Fernández et al., 1997; Muñoz et al., 1997) that are related to the emplacement of the EM2 Pájara pluton (Muñoz et al., 1997) and produce a low temperature (around 450 8C, Muñ oz and Sagredo, 1994), ductile-brittle deformation in the EM1 alkaline silicate rocks and carbonatites. Ductile deformation is channelled along metric and centimetric corridors occupied by the carbonatites, owing to their contrast in competence with the pyroxenites and nepheline-sye- nites which, in turn, exhibit more brittle deformation. In the carbonatites this deformation is superimposed on the granular, coarse-grained magmatic texture shown by these rocks when they occur outside the shear bands. Nepheline-syenites occur in this outcrop in two manners: 1) as dykes or irregular apophyses traversing the pyroxenites outside the shear corridors and, 2) as boudins or more elongated lenses within the shear zones.

\section{Geochronological background}

The geochronology of the Basal Complex of Fuerteventura has been a subject of interest over more than 20 years. On the one hand, these rocks provide a unique opportunity to determine the span of time during which the building of the island took place. On the other hand, the presence of carbona- 
tites as part of the oldest intrusive association belonging to the Basal Complex also raised interest in determining the age of their emplacement. The youngest intrusive rocks of the Basal Complex of Fuerteventura (EM3, Vega de Río Palmas alkaline Complex) have an age constrained between 21 and 18 Ma (Rona and Nalwalk, 1970; Abdel-Monem et al.,1971; Grunau et al., 1975; Le Bas et al., 1986; Cantagrel et al., 1993).

However, in recent years some discrepancies concerning the age of the older, EM1 alkaline-carbonatitic association in the island have arisen. Published data on the geochronology of the carbonatites and their most closely associated rocks are summarized in Fig. 2 and Tables 1 and 2. From them, it is apparent that most ages cluster around 24-27 Ma, both for the central-western, Ajui-Solapa sector and the north-western, Montaña Blanca-Esquinzo sector, while most of the younger ages (20-22 Ma) in the former sector have been interpreted by many authors as due to thermal resetting associated with the younger Pájara (EM2) and Vega de Río Palmas (EM3) intrusions (Le Bas et al., 1986; Sagredo et al., 1996). Furthermore, Féraud et al. (1985) reported an age interval between 24 and $17 \mathrm{Ma}$ for the main stage of emplacement of dykes associated to the Basal Complex (Fig. 2). Despite this concentration of ages around late Oligocene-early Miocene times, data from Balogh et al. (1999), not only show a much wider scattering of ages, but also comprise two different sets of $\mathrm{K}-\mathrm{Ar}$ and $\mathrm{Ar} / \mathrm{Ar}$ ages of syenites from Caleta de la Cruz, in the Ajui-Solapa sector, one of them yielding 24-27 Ma, and the other ranging from 39 up to $71 \mathrm{Ma}$ (Fig. 2). These authors considered the Ar/ Ar, 63-64 Ma data (Table 1, sample CR-S-3) as the age of intrusion of syenites belonging to an older, late Cretaceous magmatic episode, and the 24-27 Ma ages (Table 1, samples 80-40-39, CR-C-1 and CR-S-5) as corresponding to the emplacement, by means of the above described shear zones, of later syenites and carbonatites at Caleta de la Cruz. However, these authors do not report any difference between the dolderT and dyoungerT syenites. Moreover, the few data on amphibololites (amphibole-rich cumulates), which Balogh et al. (1999) consider as associated to the dolderT syenites, yield much younger ages of 23.5F 1 and 31.4F 1.4 Ma (Table 1, samples 80-

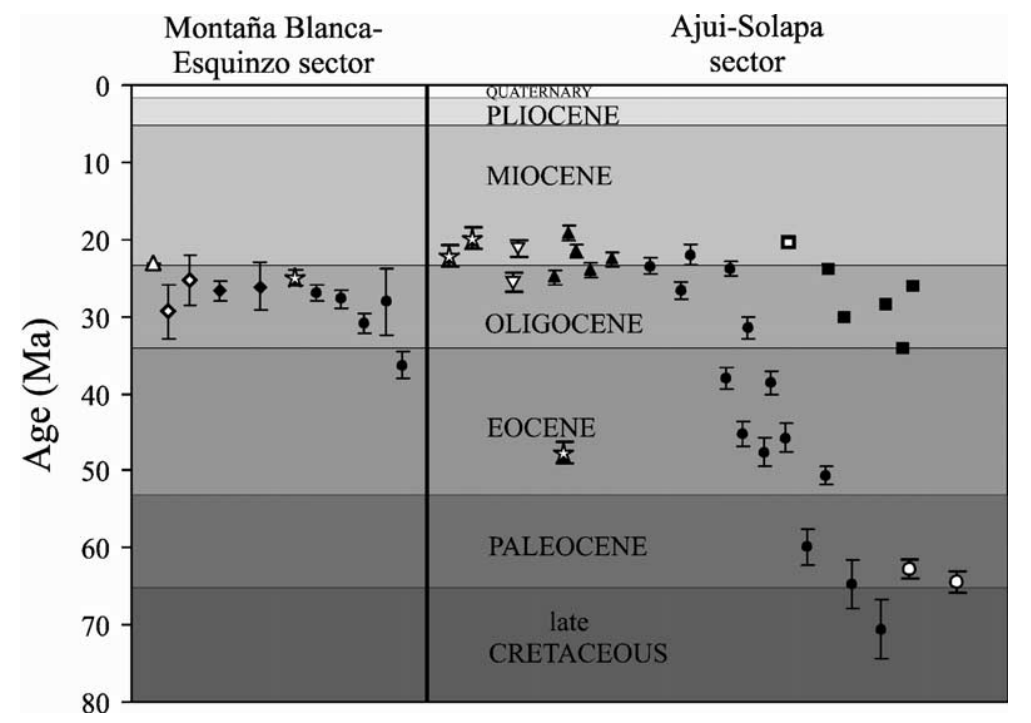

Fig. 2. Summary of ages for alkaline rocks and carbonatites from the Montaña Blanca-Esquinzo and Ajui-Solapa sectors of the Basal Complex of Fuerteventura. Data after: squares=Féraud et al. (1985), white=K-Ar age, black=Ar / Ar ages; stars=Le Bas et al. (1986), K-Ar ages; upward facing triangles=Cantagrel et al. (1993), white=U-Pb age, black=K-Ar ages; downward facing triangles=Sagredo et al. (1996); circles=Balogh et al. (1999), white=Ar-Ar ages, dark grey=K-Ar ages; diamonds=de Ignacio et al. (2002), white=apatite fission tracks ages, black=K-Ar ages. 
Table 1

Published data on the geochronology of the alkaline-carbonatitic association of the central-western, Ajui-Solapa sector of the basal complex of Fuerteventura

\begin{tabular}{|c|c|c|c|c|c|c|c|}
\hline Sample & Location & Rock type & Dating method & & $\% \mathrm{~K}$ & Age (Ma) & Reference \\
\hline F779 & Caleta Mansa & Bt-rich xenolith in ijolite & $\mathrm{K}-\mathrm{Ar}$ & biotite & 4.71 & $20 \mathrm{~F} 1$ & 1 \\
\hline 75/199 & Caleta de la Cruz & Pyroxenite & & phlogopite & 3.21 & $22 \mathrm{~F} 1$ & 1 \\
\hline В 9586 (X79) & Ajui & Ijolite & $\mathrm{K}-\mathrm{Ar}$ & biotite & 6.78 & $19.2 \mathrm{~F} 0.9$ & 2 \\
\hline B 9588 (F86) & Punta del Peñón & Syenite & & & 7.63 & $21.6 \mathrm{~F} 0.9$ & 2 \\
\hline B 9587 (F78) & Blanco & Carbonatite & & & 7.62 & $25.0 \mathrm{~F} 0.9$ & 2 \\
\hline MR-431 & Morro del & Syenite & $\mathrm{K}-\mathrm{Ar}$ & whole rock & 5.26 & $21.6 \mathrm{~F} 0.9$ & 3 \\
\hline MR-363 & Recogedero & & & & 5.76 & $25.2 \mathrm{~F} 1$ & 3 \\
\hline $80-40-39$ & Caleta de la Cruz & Amphibololite & $\mathrm{K}-\mathrm{Ar}$ & whole rock & 2.95 & $23.5 \mathrm{~F} 1$ & 4 \\
\hline CR-C-1 & & Carbonatite & & biotite & 7.04 & $23.8 \mathrm{~F} 1.0$ & 4 \\
\hline CR-S-5 & & Syenite & & whole rock & 1.20 & $26.7 \mathrm{~F} 1.1$ & 4 \\
\hline CR-S-1 & & & & whole rock & 6.58 & $38.5 \mathrm{~F} 1.5$ & 4 \\
\hline $80-40-38$ & & & & whole rock & 5.89 & $45.2 \mathrm{~F} 1.7$ & 4 \\
\hline CR-S-2 & & & & whole rock & 0.81 & $45.7 \mathrm{~F} 1.9$ & 4 \\
\hline CR-S-4 & & & & whole rock & 3.56 & $47.6 \mathrm{~F} 1.8$ & 4 \\
\hline \multirow[t]{4}{*}{ CR-S-3 } & & & $\mathrm{K}-\mathrm{Ar}$ & biotite & 2.31 & $50.6 \mathrm{~F} 1.2$ & 4 \\
\hline & & & & whole rock & 4.86 & $60.0 \mathrm{~F} 2.3$ & \\
\hline & & & $\mathrm{Ar}-\mathrm{Ar}$ & feldspar + nepheline & 5.11 & $63.1 \mathrm{~F} 0.8$ & \\
\hline & & & & feldspar & 6.57 & $64.2 \mathrm{~F} 1.0$ & \\
\hline $80-40-36$ & & & $\mathrm{~K}-\mathrm{Ar}$ & whole rock & 0.59 & 70.6 F 3.9 & 4 \\
\hline $\mathrm{R}-17$ & Punta del Peñón & Syenite & $\mathrm{K}-\mathrm{Ar}$ & whole rock & 1.60 & $22.1 \mathrm{~F} 1.3$ & 4 \\
\hline 3125 & Blanco & Carbonatite & & biotite & 7.03 & $22.7 \mathrm{~F} 0.9$ & 4 \\
\hline 3126 & & & & feldspar & 10.38 & 24.0 F 0.9 & 4 \\
\hline NAO-1 & Punta de La Nao & Carbonatite & & & 6.69 & $38.0 \mathrm{~F} 1.4$ & 4 \\
\hline 3119 & La Matanza & Amphibololite & & whole rock & 0.70 & $31.4 \mathrm{~F} 1.4$ & 4 \\
\hline 3120 & & Pyroxenite & & & 0.14 & 64.7 F 3.2 & 4 \\
\hline
\end{tabular}

References are: 1=Le Bas et al. (1986); 2=Cantagrel et al. (1993); 3=Sagredo et al. (1996); 4=Balogh et al. (1999).

40-39 and 3119 respectively). These data are, on the other hand, within the range of $\mathrm{K}-\mathrm{Ar}$ ages obtained by the authors in associated glimmeritic pyroxenites and nepheline-syenites from Caleta de la Cruz (Table 3).

\section{Sample description}

Following the above described approach, a sample of undeformed nepheline-syenite from Caleta de la Cruz was selected for $\mathrm{U}-\mathrm{Pb}$ dating (sample 086,

Table 2

Published data on the geochronology of the alkaline-carbonatitic association of the northwestern, Montaña Blanca-Esquinzo sector of the Basal Complex of Fuerteventura

\begin{tabular}{|c|c|c|c|c|c|c|c|}
\hline Sample & Location & Rock type & Dating method & & $\% \mathrm{~K}$ & Age (Ma) & Reference \\
\hline 68-SC-71 & Barranco Agua Salada & Ijolitic rock & $\mathrm{K}-\mathrm{Ar}$ & biotite & 6.93 & $25 \mathrm{~F} 1$ & 1 \\
\hline Salada-1 & Barranco Agua Salada & Carbonatite & $\mathrm{K}-\mathrm{Ar}$ & phlogopite & 7.60 & $26.9 \mathrm{~F} 1.0$ & 2 \\
\hline ES-C-4 & Las Montañetas & Carbonatite & $\mathrm{K}-\mathrm{Ar}$ & feldspar & 5.22 & $27.7 \mathrm{~F} 1.2$ & 2 \\
\hline Jablitos & Los Jablitos & Carbonatite & $\mathrm{K}-\mathrm{Ar}$ & phlogopite & 4.05 & $28.1 \mathrm{~F} 4.3$ & 2 \\
\hline ES-CII-1 & Los Jablitos & Syenite & $\mathrm{K}-\mathrm{Ar}$ & feldspar & 12.22 & $30.9 \mathrm{~F} 1.2$ & 2 \\
\hline Es-Si-1 & Barranco Esquinzo & Syenite & $\mathrm{K}-\mathrm{Ar}$ & feldspar & 7.13 & $36.3 \mathrm{~F} 1.7$ & 2 \\
\hline UL-1 & Los Jablitos & Perovskiteclinopyroxenite & $\mathrm{K}-\mathrm{Ar}$ & phlogopite & 6.77 & $26.2 \mathrm{~F} 3$ & 3 \\
\hline BM-3 & Montaña Tarabates & Amphibole, nepheline-bearing gabbro & $\mathrm{K}-\mathrm{Ar}$ & whole rock & 1.83 & $26.7 \mathrm{~F} 1.2$ & 3 \\
\hline BM-1 & Montaña Tarabates & Amphibole-apatite clinopyroxenite & Fission tracks & apatite & - & $25.4 \mathrm{~F} 3.6$ & 3 \\
\hline BM-2 & Montaña Milocho & Amphibole, nepheline-bearing gabbro & Fission tracks & apatite & - & 29.3 F 3.5 & 3 \\
\hline X 52 & Las Montañetas & Carbonatite & $\mathrm{U}-\mathrm{Pb}$ & zircon & - & $23.2 \mathrm{~F} 0.2$ & 4 \\
\hline
\end{tabular}

References are: 1=Le Bas et al. (1986); 2=Balogh et al. (1999); 3=de Ignacio et al. (2002); 4=Cantagrel et al. (1993). 
Table 3

New K-Ar ages for the alkaline-carbonatitic association at Caleta de la Cruz

\begin{tabular}{|c|c|c|c|c|c|c|c|}
\hline Sample & Location & Rock type & & $\% \mathrm{~K}$ & ${ }^{40} \mathrm{Ar}(\mathbf{A l} / \mathrm{g})$ & $\%{ }^{40} \mathrm{Ar}_{\mathrm{rad}}$ & Age (Ma) \\
\hline 505 & Caleta de la Cruz & Glimmeritic pyroxenite & whole rock & 1.60 & 1.6699 & 87.66 & 26.7 F3.2 \\
\hline 744 & & Nepheline-syenite & whole rock & 3.77 & 3.9273 & 48.15 & $26.6 \mathrm{~F} 1.0$ \\
\hline 622 & & Mica-bearing pyroxenite & phlogopite & 6.72 & 0.614 & 82.4 & $23.4 \mathrm{~F} 0.6$ \\
\hline
\end{tabular}

Fig. 1). This nepheline-syenite is similar to those described by Balogh et al. (1999). It is composed of clinopyroxene, nepheline, alkali feldspar, biotite, titanite, fluorapatite and zircon, and displays $\mathrm{K}_{2} \mathrm{O}=4.36$ wt.\% and high $\mathrm{Zr}$ (1248 ppm). Clinopyroxene is zoned, with diopsidic cores and aegirine-augite rims. Biotite occurs in small crystals, with $\mathrm{K}_{2} \mathrm{O}=9$ 10 and 1-2 wt.\% $\mathrm{TiO}_{2}$. Nepheline $\left(\mathrm{Ne}_{75-78} \mathrm{Ks}_{18-20}\right.$ $\left.\mathrm{Qtz}_{3-6}\right)$ is idiomorphic, and shows ubiquitous alteration to cancrinite at its rims, in association with interstitial hydrothermal phases such as sodalite. Inclusions of clinopyroxene, feldspar and mica are common in nepheline, the former being particularly abundant. Alkali feldspar occurs in idiomorphic-tosubidiomorphic crystals displaying high compositional heterogeneity, showing abundant inclusions of nosean, clinopyroxene, titanite, biotite and calcite. The electron microprobe study of these feldspars reveals complex zoning (Fig. 3, Table 5): the cores, which are patchy, are formed by intergrowths of very pure albite and $\mathrm{K}$-feldspar $\left(\mathrm{Ab}_{98}\right.$ and $\mathrm{Or}_{82-86}$ respec- tively; Fig. 3, Table 5). These cores are surrounded by an intermediate, light-colored zone consisting of Barich feldspar hyalophane (Fig. 3, Table 5), where K has been substituted by $\mathrm{Ba}$ (8.4 to $9.5 \mathrm{wt}$.\% $\mathrm{BaO}$ ). The rims of these crystals are composed of K-feldspar showing a similar composition to that forming the cores, without $\mathrm{BaO}$ and with less intergrown albite (Fig. 3, Table 5), Accessory fluorapatite is rich in $\mathrm{SrO}$ (3-4 wt.\%) and slightly zoned in the REE (1.4-2.4 wt.\% total $\mathrm{REE}_{2} \mathrm{O}_{3}$ from core to rim).

Zircons from syenite 086 are generally subidiomorphic to idiomorphic, sometimes skeletal with transparent to yellow hues and often displaying a pseudo-octahedral appearance owing to the poor development of prismatic faces typical of zircons crystallized in alkaline magmas. Size was usually between approximately 175 and 325 Am (long axis) with a length to breadth ratio typically between $1.5: 1$ and $1: 1$. Electron microprobe analyses of these zircons (Fig. 4, Table 6) showed a very homogeneous, quite pure composition without zoning pat-

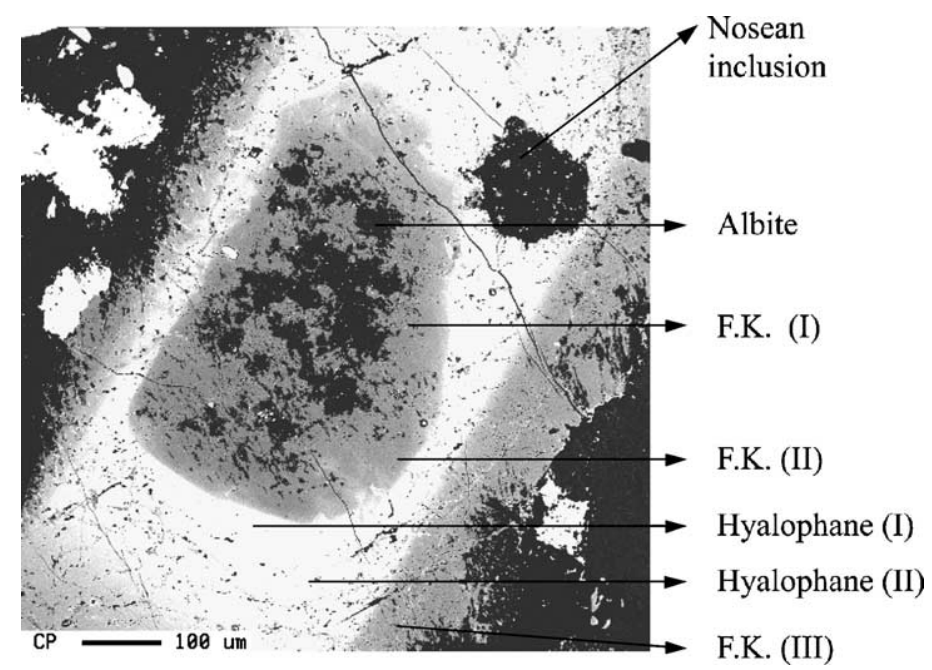

Fig. 3. Backscattered electron image showing complex zoning in alkali feldspar from sample 086 from Caleta de la Cruz. 


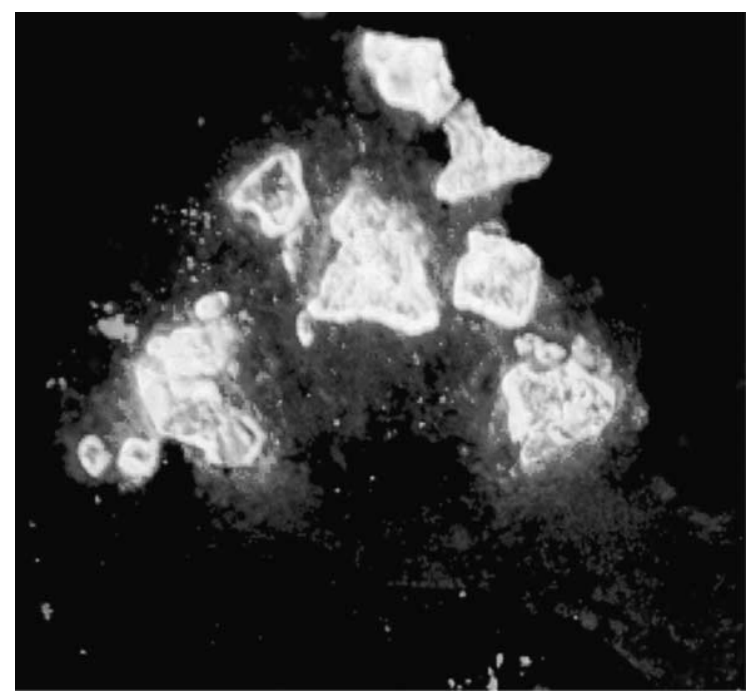

Fig. 4. Cathodoluminiscence image (80 times magnification) of zircons from sample 086 from Caleta de la Cruz.

terns that is also apparent from their cathodoluminiscence study (Fig. 4, Table 6).

\section{Analytical techniques}

Zircons were separated at the Complutense University of Madrid by conventional techniques involving heavy fraction enrichment on a Wilfley table, density separation using di-iodomethane and magnetic separation using a Frantz isodynamic separator. Zircons were picked in alcohol under a binocular microscope and subsequently set in a synthetic resin mount, polished and cleaned in a warm $\mathrm{HNO}_{3}$ ultrasonic bath. U-Th$\mathrm{Pb}$ analyses were performed at The Natural History Museum (London) using a $213 \mathrm{~nm}$ Nd:YAG laser ablation system (New Wave Research, USA) coupled to a quadrupole based ICP-MS (PlasmaQuad 3, Thermo Elemental, UK) with an enhanced sensitivity (S-option) interface. To reduce the effects of interelement laser induced fractionation the zircons were ablated at the lowest power density required to couple to the sample (pulse energy=0.15 mJ per pulse).

Samples and standard were ablated in an air-tight sample chamber flushed with an argon-helium mixture for sample transport. The laser was focused on the sample surface and energy density was kept constant for each analysis.
The zircons were rastered along lines 30 to $70 \mathrm{Am}$ long using a constant raster speed for each analysis. The nominal beam diameter was $45 \mathrm{Am}$ and resulting ablation pits were approximately 35-45 X 40-80 Am (depth variable according to raster length). Data for sample zircons were collected for up to $150 \mathrm{~s}$ per analysis, with a gas (Ar F He) background taken during the initial $60 \mathrm{~s}$ of each analysis (for standard and sample). Data were collected in discrete runs of 20 analyses, comprising 12 unknowns bracketed before and after by 4 analyses of the standard zircon 91500 (Wiedenbeck et al., 1995). The weighted averages (2r) of ${ }^{206} \mathrm{~Pb} /{ }^{238} \mathrm{U}$ and ${ }^{207} \mathrm{~Pb} /{ }^{206} \mathrm{~Pb}$ ages for the 91500 standard (run as an unknown) during analyses are: $1062.8 \mathrm{~F} 2$ Ma $(n=8$, certified ID-TIMS ${ }^{206} \mathrm{~Pb} /{ }^{238} \mathrm{U}$ age: $\left.1062.4 \mathrm{~F} 0.4 \mathrm{Ma}\right)$ and $1064.5 \mathrm{~F} 2.5$ Ma $\left(n=8\right.$, certified ID-TIMS ${ }^{207} \mathrm{~Pb} /{ }^{206} \mathrm{~Pb}$ age: 1065.4 F 0.3 Ma). These figures are consistent with homogeneous elemental $\mathrm{U} / \mathrm{Pb}$ ratios in the standard zircon 91500. The reproducibility of $\mathrm{U}-\mathrm{Pb}$ ratios is further checked by within-run analyses of other inhouse zircons previously characterised by repeated ID-TIMS measurements (e.g. ZD-7 zircon reported in Jeffries et al., 2003).

Preliminary selection of background and analysis signal intensities, isotope ratio and age calculations were performed using dLAMTRACET, a macro based spreadsheet written by Simon Jackson, Macquarie University, Australia. Background and mass bias corrected signal intensities and counting statistics were calculated for each isotope. Reported errors on individual analyses are based solely on counting statistics. Concordia age calculations, weighted averages, intercept ages and plotting of concordia diagrams were performed using Isoplot 3.00 (details of these calculations are described in Ludwig, 2003).

For each analysis, time-resolved isotope ratio signals were obtained and then carefully studied to ensure that only flat stable signal intervals were included in the age calculations. Given that selection of appropriate signal intervals is critical in obtaining the most accurate ratios for each analysis, the following features were always avoided: i) inclusions of minerals containing $\mathrm{U}, \mathrm{Th}, \mathrm{Pb}$; ii) $\mathrm{U}-\mathrm{Th}-\mathrm{Pb}$ chemical zonation; iii) alteration or fracture zones with high common $\mathrm{Pb}$; iv) inconsistent behaviour of the $\mathrm{U}-\mathrm{Pb}$ and $\mathrm{Th}-\mathrm{Pb}$ systems, i.e. the possibility that 
thorogenic lead $\left({ }^{208} \mathrm{~Pb}\right)$ and uranogenic lead $\left({ }^{207} \mathrm{~Pb}\right.$, ${ }^{206} \mathrm{~Pb}$ ) may not behave coherently in processes such as metamictization, resulting in inconsistent $\mathrm{U}-\mathrm{Pb}$ and $\mathrm{Th}-\mathrm{Pb}$ ages; v) U-Pb or $\mathrm{Th}-\mathrm{Pb}$ elemental fractionation. These features are identifiable by observation of both raw counts of integrated sweeps and isotope ratio time-integrated signals. Parts of the analysis that show any of the above features or any combination of them were systematically excluded from age calculation. Those analyses in which all the signals are affected by the above features were rejected. Further details on the analytical methodology and data treatment are given in Jeffries et al. (2003).

\section{6. $\mathrm{U}-\mathrm{Pb}$ results}

A total of 36 analyses were performed on zircon grains from syenite 086 . Of those, 16 were rejected because their isotope-ratio signals were highly disturbed by ablation of inclusions. The results of the
20 selected analyses are reported in Table 4 and Fig. 5.

In all analyses the amount of ${ }^{207} \mathrm{~Pb}$ was too low to allow reliable measurement of the ${ }^{207} \mathrm{~Pb} /{ }^{206} \mathrm{~Pb}$ ratios and therefore the ${ }^{207} \mathrm{~Pb} /{ }^{206} \mathrm{~Pb}$ ratios reported in Table 4 reflect poor counting statistics. The most reliable measurements were obtained for the ${ }^{206} \mathrm{~Pb} /{ }^{238} \mathrm{U}$ ratio owing to the higher abundance of ${ }^{206} \mathrm{~Pb}$. A one-variable statistical analysis performed on the data set of the twenty measured ${ }^{206} \mathrm{~Pb} /{ }^{238} \mathrm{U}$ ages (Table 4) shows that the age population has the features of a normal distribution with values of standardized skewness (1.16) and standardized kurtosis (- 0.12) that are well within the range of values characteristic of normal distributions $(-2$ to +2$)$. This is also shown in the linearised probability plot of Fig. 5A, where all the measured (i.e. uncorrected) ${ }^{206} \mathrm{~Pb} /{ }^{238} \mathrm{U}$ ages plot on the same linear trend (Ludwig, 2003). Since data affected by $\mathrm{Pb}$ loss or presence of inherited $\mathrm{Pb}$ are not normally distributed, it is reasonable to assume that variation of the measured ${ }^{206} \mathrm{~Pb} /{ }^{238} \mathrm{U}$ ratios at the

Table 4

LA-ICP-MS U-Th-Pb results

\begin{tabular}{|c|c|c|c|c|c|c|c|c|c|c|c|c|c|c|c|}
\hline \multirow{4}{*}{$\begin{array}{l}\text { Sample } \\
086 \\
\text { Anal. \# }\end{array}$} & \multicolumn{9}{|c|}{ Isotopic ratios and $2 s$ errors } & \multicolumn{6}{|c|}{ Ages and 2s absolute errors (Ma) } \\
\hline & \multicolumn{9}{|c|}{ Measured } & \multicolumn{2}{|c|}{ Uncorrected } & \multicolumn{2}{|c|}{$\begin{array}{l}{ }^{207} \mathrm{~Pb} \\
\text { corrected }\end{array}$} & \multicolumn{2}{|c|}{ Uncorrected } \\
\hline & ${ }^{206} \mathrm{~Pb} /$ & $\mathrm{F} 2 \mathrm{~s}$ & ${ }^{207} \mathrm{~Pb} /$ & $\mathrm{F} 2 \mathrm{~s}$ & ${ }^{207} \mathrm{~Pb} /$ & $\mathrm{F} 2 s$ & ${ }^{208} \mathrm{~Pb} /$ & $\mathrm{F} 2 s$ & & ${ }^{206} \mathrm{~Pb} /$ & F2- & ${ }^{206} \mathrm{~Pb} /$ & $\overline{\text { F2- }}$ & ${ }^{208} \mathrm{~Pb} /$ & F 2- \\
\hline & ${ }^{238} \mathrm{U}$ & & ${ }^{235} \mathrm{U}$ & & ${ }^{206} \mathrm{~Pb}$ & & ${ }^{232} \mathrm{Th}$ & & ${ }^{232} \mathrm{Th}$ & ${ }^{238} \mathrm{U}$ & $S$ & ${ }^{238} \mathrm{U}$ & $S$ & ${ }^{232} \mathrm{Th}$ & $S$ \\
\hline ja30c05 & 0.0039 & 0.0001 & 0.0258 & 0.0008 & 0.0480 & 0.0013 & 0.0012 & 0.00003 & 5.00 & 25.1 & 0.4 & 25.0 & 0.4 & 25.0 & 1.2 \\
\hline ja30с09 & 0.0041 & 0.0002 & 0.0478 & 0.0037 & 0.0852 & 0.0061 & 0.0014 & 0.00003 & 0.43 & 26.4 & 1.0 & 25.1 & 1.0 & 27.3 & 1.2 \\
\hline ja30c10 & 0.0040 & 0.0001 & 0.0315 & 0.0020 & 0.0571 & 0.0025 & 0.0013 & 0.00002 & 0.53 & 25.7 & 0.8 & 25.4 & 0.8 & 26.9 & 0.6 \\
\hline ja30c11 & 0.0040 & 0.0001 & 0.0326 & 0.0014 & 0.0590 & 0.0023 & 0.0012 & 0.00003 & 0.74 & 25.7 & 0.8 & 25.3 & 0.8 & 24.8 & 1.2 \\
\hline ja30c15 & 0.0040 & 0.0001 & 0.0327 & 0.0029 & 0.0586 & 0.0045 & 0.0011 & & 0.46 & 25.7 & 0.8 & 25.3 & 0.8 & 22.6 & 0.8 \\
\hline ja31a06 & 0.0040 & 0.0002 & 0.0319 & 0.0035 & 0.0584 & 0.0056 & 0.0012 & 0.00006 & 1.40 & 25.7 & 1.0 & 25.3 & 1.0 & 24.0 & 2.0 \\
\hline fe07a05 & 0.0040 & 0.0002 & 0.0428 & 0.0032 & 0.0771 & 0.0053 & 0.0012 & 0.00004 & 0.15 & 25.7 & 1.4 & 24.7 & 1.4 & 23.2 & 1.6 \\
\hline ja30c12 & 0.0040 & 0.0001 & 0.0260 & 0.0008 & 0.0476 & 0.0013 & 0.0012 & 0.00001 & 0.57 & 25.7 & 0.4 & 25.7 & 0.4 & 24.4 & 0.4 \\
\hline fe07a07 & 0.0040 & 0.0002 & 0.0264 & 0.0021 & 0.0476 & 0.0029 & 0.0010 & 0.00003 & 0.31 & 25.7 & 1.0 & 25.7 & 1.0 & 20.6 & 1.2 \\
\hline $\mathrm{fe} 07 \mathrm{a} 08$ & 0.0039 & 0.0001 & 0.0251 & 0.0011 & 0.0469 & 0.0021 & 0.0010 & 0.00001 & 0.57 & 25.1 & 0.6 & 25.1 & 0.6 & 20.2 & 0.6 \\
\hline fe07a09 & 0.0039 & 0.0001 & 0.0258 & 0.0012 & 0.0475 & 0.0022 & 0.0009 & 0.00002 & 0.39 & 25.1 & 0.8 & 25.1 & 0.8 & 19.0 & 0.8 \\
\hline fe07a 10 & 0.0039 & 0.0001 & 0.0298 & 0.0016 & 0.0552 & 0.0037 & 0.0010 & 0.00002 & 0.37 & 25.1 & 0.6 & 24.8 & 0.6 & 20.6 & 0.6 \\
\hline fe07a11 & 0.0040 & 0.0001 & 0.0376 & 0.0031 & 0.0688 & 0.0043 & 0.0013 & 0.00006 & 1.15 & 25.7 & 1.0 & 25.0 & 1.0 & 25.0 & 2.0 \\
\hline fe07a13 & 0.0039 & 0.0001 & 0.0240 & 0.0013 & 0.0452 & 0.0020 & 0.0011 & 0.00005 & 6.65 & 25.1 & 0.8 & 25.1 & 0.8 & 22.0 & 2.0 \\
\hline fe07a14 & 0.0042 & 0.0002 & 0.0327 & 0.0027 & 0.0563 & 0.0039 & 0.0012 & 0.00005 & 0.86 & 27.0 & 1.4 & 26.7 & 1.4 & 24.2 & 2.0 \\
\hline fe07a15 & 0.0040 & 0.0001 & 0.0277 & 0.0013 & 0.0503 & 0.0024 & 0.0011 & 0.00003 & 2.08 & 25.7 & 0.6 & 25.6 & 0.6 & 22.2 & 1.2 \\
\hline fe07a16 & 0.0041 & 0.0001 & 0.0272 & 0.0014 & 0.0482 & 0.0028 & 0.0011 & 0.00004 & 2.30 & 26.4 & 0.6 & 26.3 & 0.6 & 21.2 & 1.4 \\
\hline fe07b05 & 0.0041 & 0.0003 & 0.0264 & 0.0025 & 0.0463 & 0.0025 & 0.0011 & 0.00003 & 0.59 & 26.4 & 1.8 & 26.4 & 1.8 & 21.6 & 1.2 \\
\hline fe07b11 & 0.0039 & 0.0002 & 0.0297 & 0.0016 & 0.0550 & 0.0031 & 0.0011 & 0.00003 & 0.56 & 25.1 & 1.4 & 24.8 & 1.4 & 22.2 & 1.0 \\
\hline fe07b12 & 0.0041 & 0.0002 & 0.0291 & 0.0016 & 0.0517 & 0.0034 & 0.0011 & 0.00004 & 0.30 & 26.4 & 1.2 & 26.2 & 1.2 & 22.6 & 1.4 \\
\hline
\end{tabular}

Analyses in bold: repeated analyses on grain \#12. ${ }^{207}$ Pb corrected ages: calculated using the algorithm of Ludwig (2003). 
Table 5

Feldspar microprobe analyses

\begin{tabular}{lrrrrrr}
\hline & Albite & \multicolumn{2}{c}{ KFeldspar } & \multicolumn{2}{c}{ Hyalophane } & KFeldspar \\
& & $\mathrm{I}$ & $\mathrm{II}$ & \multicolumn{1}{c}{$\mathrm{I}$} & $\mathrm{II}$ & $\mathrm{III}$ \\
\hline $\mathrm{SiO}_{2}$ & 66.19 & 63.23 & 62.66 & 59.57 & 60.02 & 62.00 \\
$\mathrm{Al}_{2} \mathrm{O}_{3}$ & 19.80 & 18.61 & 18.99 & 20.27 & 20.14 & 19.91 \\
$\mathrm{FeO}$ & 0.26 & 0.16 & 0.32 & 0.13 & 0.17 & 1.12 \\
$\mathrm{CaO}$ & 0.04 & 0.01 & 0.01 & - & - & 0.02 \\
$\mathrm{Na}{ }_{2} \mathrm{O}$ & 11.61 & 1.45 & 1.89 & 2.11 & 2.30 & 2.52 \\
$\mathrm{~K}_{2} \mathrm{O}$ & 0.25 & 14.68 & 13.51 & 11.67 & 11.59 & 12.76 \\
$\mathrm{BaO}$ & - & 0.22 & 1.39 & 5.21 & 4.62 & 0.53 \\
$\mathrm{SrO}$ & 0.10 & 0.27 & 0.35 & 0.77 & 0.82 & 0.40 \\
$\mathrm{Total}$ & 98.48 & 98.71 & 99.27 & 100.05 & 99.97 & 99.49 \\
& & & & & & \\
$\mathrm{Si}$ & 11.815 & 11.850 & 11.730 & 11.374 & 11.403 & 11.536 \\
$\mathrm{Al}$ & 4.168 & 4.111 & 4.190 & 4.562 & 4.510 & 4.368 \\
$\mathrm{Fe}{ }^{3+}$ & 0.039 & 0.026 & 0.051 & 0.021 & 0.027 & 0.175 \\
$\mathrm{Ca}$ & 0.007 & 0.001 & 0.002 & - & - & 0.005 \\
$\mathrm{Na}$ & 4.020 & 0.526 & 0.686 & 0.781 & 0.848 & 0.907 \\
$\mathrm{~K}$ & 0.056 & 3.510 & 3.226 & 2.843 & 2.808 & 3.028 \\
$\mathrm{Ba}$ & - & 0.016 & 0.102 & 0.390 & 0.344 & 0.039 \\
$\mathrm{Sr}$ & 0.010 & 0.030 & 0.037 & 0.086 & 0.091 & 0.043 \\
& & & & & & \\
$\mathrm{Or}$ & 1.4 & 86.4 & 82.1 & 78.8 & 77.0 & 76.0 \\
$\mathrm{Ab}$ & 98.2 & 12.9 & 16.9 & 19.0 & 20.7 & 22.5 \\
$\mathrm{An}$ & 0.5 & 0.8 & 1.0 & 2.1 & 2.2 & 1.6 \\
& & & & & & \\
$\mathrm{Ba}$ & - & 0.4 & 2.5 & 9.5 & 8.4 & 1.0 \\
\hline & & & & & &
\end{tabular}

precision reported is not due to natural causes (presence of slightly older cores or differential $\mathrm{Pb}$ loss) and can be attributed to analytical uncertainty alone. It should also be noted that the oldest and youngest uncorrected ${ }^{206} \mathrm{~Pb} /{ }^{238} \mathrm{U}$ ages (Table 4) are within analytical error (2r) of one another, a feature that would not be observed in 20 repeated analyses of a naturally discordant (Pb-loss and/or inherited $\mathrm{Pb}$ ) zircon population. This allows the use of the ${ }^{207} \mathrm{~Pb}$

correction for common $\mathrm{Pb}$ (e.g. Ludwig, 2003) which assumes that the radiogenic ${ }^{206} \mathrm{~Pb} /{ }^{238} \mathrm{U}$ and ${ }^{207} \mathrm{~Pb} /{ }^{206} \mathrm{~Pb}$ ages are concordant, and are numerically equivalent to the intercept age obtained by regressing the uncorrected ${ }^{238} \mathrm{U} /{ }^{206} \mathrm{~Pb}$ and ${ }^{207} \mathrm{~Pb} /{ }^{206} \mathrm{~Pb}$ ratios through the corresponding common ${ }^{207} \mathrm{~Pb} /{ }^{206} \mathrm{~Pb}$ ratio (i.e. subtracting the common $\mathrm{Pb}$ contribution to the apparent age). This is the correction method most frequently used in young zircons with low ${ }^{207} \mathrm{~Pb}$. The ${ }^{204} \mathrm{~Pb}$ correction cannot be applied to the LA-ICP-MS $\mathrm{U}-\mathrm{Pb}$ analyses reported here because of the presence of ${ }^{204} \mathrm{Hg}$ in the Ar carrier gas which produces an isobaric interference with ${ }^{204} \mathrm{~Pb}$ (e.g. Andersen,
2002; Jeffries et al., 2003). Table 4 reports the ${ }^{207} \mathrm{~Pb}$ corrected ages and the corresponding corrected ratios have been used to construct the Wetherill concordia plot shown in Fig. 5B.

The ${ }^{207} \mathrm{~Pb}$ corrected ages reported in Table 4 have been obtained using the algorithm of Ludwig (2003) and are numerically equivalent to the intercept ages obtained by regressing the uncorrected ${ }^{238} \mathrm{U} /{ }^{206} \mathrm{~Pb}$ and ${ }^{207} \mathrm{~Pb} /{ }^{206} \mathrm{~Pb}$ ratios through the Stacey and Kramers (1975) common ${ }^{207} \mathrm{~Pb} /{ }^{206} \mathrm{~Pb}$ at $0 \mathrm{Ma}$ with an arbitrarily assigned error of F 0.1 (cf. Zeck and Whitehouse, 1999). In this case, the use of an estimated common lead composition for the magma is precluded by the lack of data such as measured $\mathrm{Pb}$ isotopes in feldspar or other Pb-bearing magmatic minerals. Provided that inclusions (usual carriers of magmatic common $\mathrm{Pb}$ ) were avoided in age calculations (see above) the most likely source of common $\mathrm{Pb}$ is sample contamination (in small cracks) during

the edge of grains. In both cases the use of present day average terrestrial common $\mathrm{Pb}$ composition is the most appropriate.

The crystallisation age of the zircons in the syenite can be calculated in several numerical/graphical ways that are illustrated in Fig. 5. Fig. 5B is a Wetherill concordia plot constructed using the ${ }^{207} \mathrm{~Pb}$ corrected ratios of the 20 analyses and calculating a pooled concordia age (sensu Ludwig, 1998). The resulting

Table 6

Zircon microprobe analyses

\begin{tabular}{lcr} 
& Core & \multicolumn{1}{c}{ Rim } \\
\hline $\mathrm{SiO}_{2}$ & 31.68 & 31.76 \\
$\mathrm{Al} \mathrm{O}_{2}{ }_{3}$ & - & 0.01 \\
$\mathrm{FeO}$ & 0.09 & 0.06 \\
$\mathrm{ThO}_{2}$ & 0.09 & 0.04 \\
$\mathrm{UO}_{2}$ & 0.26 & 0.07 \\
$\mathrm{Y}_{2} \mathrm{O}_{3}$ & 0.12 & 0.07 \\
$\mathrm{ZrO}_{2}$ & 66.88 & 67.00 \\
$\mathrm{HfO}_{2}$ & 0.41 & 0.37 \\
$\mathrm{RE}_{2} \mathrm{O}_{3}$ & 0.38 & 0.36 \\
$\mathrm{Total}$ & 99.91 & 99.74 \\
$\mathrm{Si}$ & & \\
$\mathrm{Zr}^{+} \mathrm{Hf}$ & 3.92 & 3.92 \\
$\mathrm{Fe}$ & 4.04 & 4.05 \\
$\mathrm{UO}_{2}$ & 0.01 & 0.01 \\
$\mathrm{Y}_{2} \mathrm{O}_{3}$ & 0.01 & - \\
$\mathrm{RE}_{2} \mathrm{O}_{3}$ & 0.01 & - \\
& 0.02 & 0.02 \\
\hline
\end{tabular}



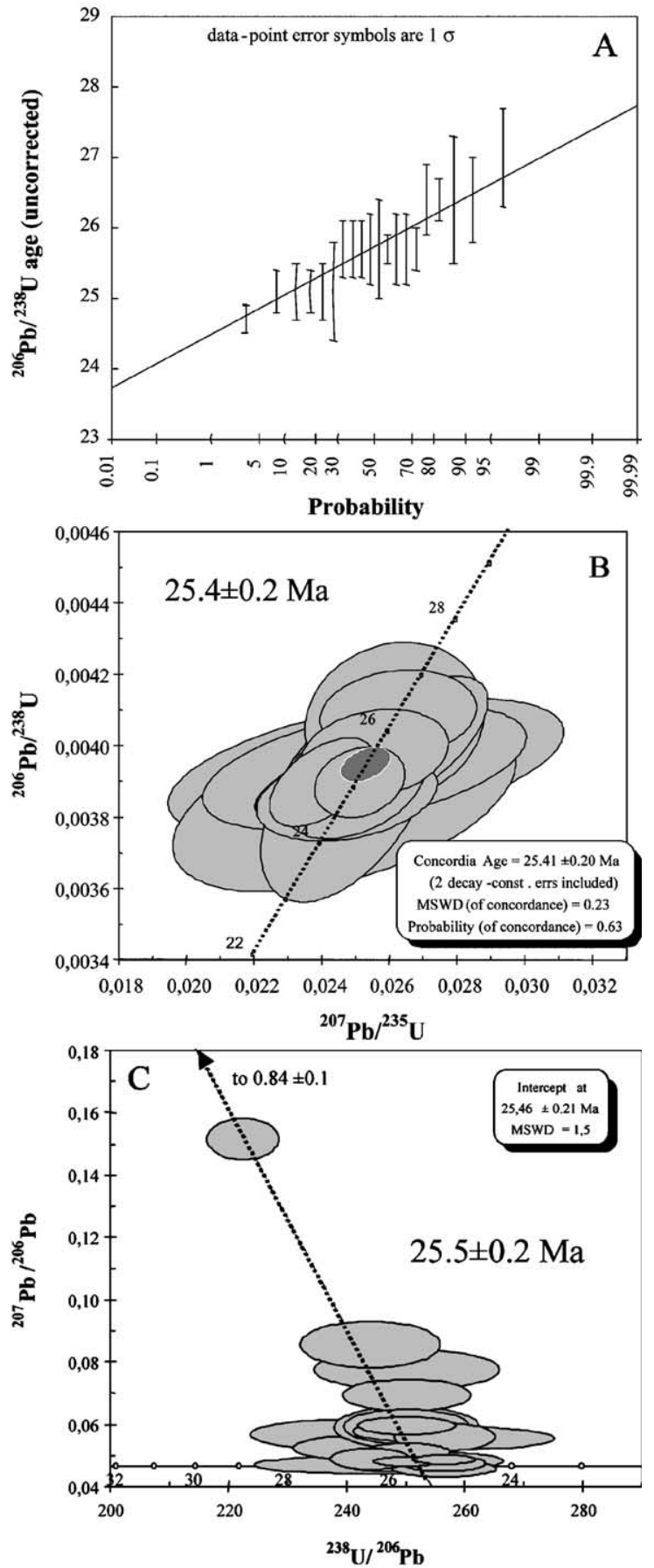

Fig. 5. A) Linearised probability plot (Ludwig, 2003) constructed using the uncorrected ${ }^{206} \mathrm{~Pb} /{ }^{238} \mathrm{U}$ ages. B) U-Pb concordia diagram showing the concordia age (sensu Ludwig, 1998) obtained using the ${ }^{207} \mathrm{~Pb}$ corrected ratios (error ellipses represent 2r uncertainties). C) Tera-Wasserburg plot constructed using the uncorrected ratios and showing the intercept age of a discordia forced through present-day common lead $\left({ }^{207} \mathrm{~Pb} /{ }^{206} \mathrm{~Pb}\right)$ composition. Further explanation to all three figures in main text. 
age and error using this approach are $25.4 \mathrm{~F} 0.2 \mathrm{Ma}$ (2r). This age is reproduced using the same approach with 5 analyses on a large grain (bold type in Table 4) which yields a concordia age of 25.3 F 0.3 Ma (2r).

Fig. 5C shows the intercept age obtained using the uncorrected ${ }^{238} \mathrm{U} /{ }^{206} \mathrm{~Pb}$ and ${ }^{207} \mathrm{~Pb} /{ }^{206} \mathrm{~Pb}$ ratios on a Tera-Wasserburg plot and regressing through Stacey and Kramers (1975) common ${ }^{207} \mathrm{~Pb} /{ }^{206} \mathrm{~Pb}$ at $0 \mathrm{Ma}$. The age and error obtained are 25.5F 0.2 Ma (2r), within error of the previously reported ages.

These ages are also within analytical uncertainty of the uncorrected (25.6 F $0.2 \mathrm{Ma}$ ) and ${ }^{207} \mathrm{~Pb}$ corrected (25.3 F 0.2 Ma) weighted average of the ${ }^{206} \mathrm{~Pb} /{ }^{238} \mathrm{~Pb}$ ages.

We have considered the possible effect of ${ }^{230} \mathrm{Th}$ disequilibrium (e.g. Schärer 1984) on the age of the zircons. Calculations based on the equation of Schärer (1984) and using a Th / U value of 2.55 for the whole rock (Sagredo and Muñoz, unpublished data) and the $(\mathrm{Th} / \mathrm{U})_{\text {zircon }}$ measured by LA-ICP-MS analyses show that the age shift between disequilibrium corrected and uncorrected ages ranges from 0.1 to $0.01 \mathrm{Ma}$, well below the precision of individual analyses reported here and therefore not meaningful to the final age at the precision reported.

Based on the above, the crystallisation age of zircon in the syenite is best described as 25.4F 0.4 Ma.

\section{Previously reported and newly contributed ages}

The data presented and discussed above constrain the crystallisation age of zircons in syenites from Caleta de la Cruz, in the Ajui-Solapa sector of the Fuerteventura Basal Complex. Althogh U-Pb dating by laser ablation ICP-MS is still in full development, recent research has shown considerable advances and its usefulness to date young zircons (e.g. the Gunung Celeng zircon, dated at $7 \mathrm{Ma}$, Jackson et al., 2004). This $\mathrm{U}-\mathrm{Pb}$ age is consistent with most of the previously reported $\mathrm{K}-\mathrm{Ar}, \mathrm{U}-\mathrm{Pb}$ and apatite fission tracks ages on the EM1 alkaline silicate rocks and carbonatites (see Tables 1, 2 and 3). The possible existence of older intrusive rocks in this association of the Basal Complex was first proposed by Le Bas et al. (1986) who considered that magmatism in Fuerteventura had started by Paleocene-lower Eocene times. However, this consideration was based solely in a $48 \mathrm{Ma}, \mathrm{K}-\mathrm{Ar}$ age of a dyke which those authors described as crosscutting a gabbro-pyroxenite they labelled as PX1. Consequently, they placed a gabbroic-pyroxenitic unit PX1 at the limit between the Paleocene and the Eocene. Moreover, as the PX1 unit was observed to intrude carbonatites and ijolites, Le Bas et al. (1986) placed an even older unit at the limit of the upper Cretaceous with the Paleocene (65 Ma), formed by the Ajui-Solapa carbonatite/ijolite and still earlier gabbropyroxenite and syenite, whereas for the northern, Montaña Blanca-Esquinzo outcrops of carbonatite/ijolite on the island they propose a $25 \mathrm{Ma}$ age. In this line, Balogh et al. (1999), proposed a Cretaceous (63$64 \mathrm{Ma}$ ), ultramafic-syenitic series, and an upper Oligocene-Miocene, syenite-carbonatite series.

However, it is apparent from the description by Le Bas et al. (1986) that their PX1 unit corresponds to the outermost part of the Pájara pluton, which intrudes the EM1 alkaline silicate rocks and carbonatites producing a contact metamorphic aureole in them. Sagredo et

A
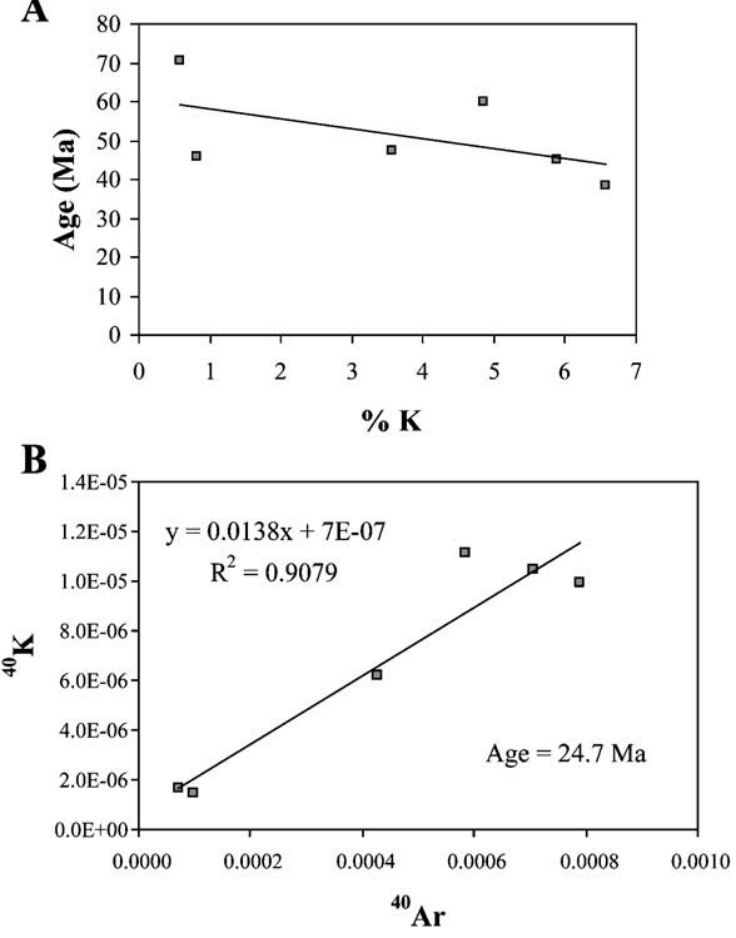

Fig. 6. A) Progressive linear decrease of obtained age vs. K content in syenite samples from Caleta de la Cruz. Data after Balogh et al. (1999). B) ${ }^{40} \mathrm{~K}$ vs. ${ }^{40} \mathrm{Ar}$ diagram for the same samples showing a linear fit with a slope corresponding to an age of 24.7 Ma. 
al. (1996) reported an age of 25.2 F 1 Ma for the crystallisation age of nepheline-syenites unaffected by the contact metamorphism of the Pájara pluton, and an age of 21.6 F 0.9 Ma for the thermal resetting of the nepheline-syenites inside the contact aureole. These results are also in agreement with an $\mathrm{Ar} / \mathrm{Ar}$ single plateau age of 23.8 $\mathrm{Ma}$ and a $\mathrm{K}-\mathrm{Ar}$ age of 20.3 F 0.6 Ma after Féraud et al. (1985), obtained on basaltic dykes respectively unaffected and affected by the thermal aureole of the Pájara pluton. In this sense, our $\mathrm{K}-\mathrm{Ar}$ data from rocks belonging to the EM1 alkaline-carbonatitic association at Caleta de la Cruz (Table 3), yield consistent ages with the thermally unresetted samples of Féraud et al. (1985) and Sagredo et al. (1996), as well as with the new U-Pb data.

However, as mentioned above, there is a wide scattering in the doldT $\mathrm{K}-\mathrm{Ar}$ ages obtained by Balogh et al. (1999) from Caleta de la Cruz syenites (from 38.5 to $70.6 \mathrm{Ma}$, Table 1). Similar scattering has been attributed in other cases to incorporation of excess $\mathrm{Ar}$ in the rocks (e.g. Dalrymple and Moore, 1968). The quoted ages from Caleta de la Cruz syenites show progressively older ages with decreasing $\mathrm{K}$ content in the rock (Fig. 6A). Variations in the K content between samples can affect the magnitude of the apparent age, as samples with low $\mathrm{K}$ content are more susceptible to the possible effects of excess Ar (Harrison and McDougall, 1981). When plotted in a ${ }^{40} \mathrm{Ar}_{\text {rad }}{ }^{40} \mathrm{~K}$ diagram, whole rock, $\mathrm{K}-\mathrm{Ar}$ data for Caleta de la Cruz syenites fit remarkably well a linear array, the slope of which would yield an age of 24.7 Ma (Fig. 6B), in agreement with our U-Pb data.

Based on the new U-Pb data presented herein and their agreement both with our $\mathrm{K}-\mathrm{Ar}$ data, and with most of the already reported $\mathrm{K}-\mathrm{Ar}$ and $\mathrm{Ar} / \mathrm{Ar}$ data on the literature (Fig. 2), we consider that the alkaline-carbonatitic activity in the island of Fuerteventura took place in a single episode at approximately $25 \mathrm{Ma}$. This is further supported by comparison with the coeval, northwestern outcrops of alkaline silicate rocks and carbonatites from Montaña BlancaEsquinzo. The observed field relationships between the different lithologies constituting this association of rocks are very similar to those described at Caleta de la Cruz (Muñ oz et al., 2003). Thus, in both sectors, the ultramafic and mafic rocks are cumulates, pervaded and traversed by more differentiated, nepheline-syenites and carbonatites forming small masses, dykes and veins. Based on the study of volcanic materials of equivalent composition and age (22-25 Ma) to our described association of alkaline silicate rocks and carbonatites in the AjuiSolapa sector (Ibarrola et al., 1989; Muñoz et al., 2002), we propose that the alkaline-carbonatitic magmatic event (EM1) of the Basal Complex of Fuerteventura comprised: a series of intrusive rocks, from alkaline pyroxenites and melteigites-ijolites to nepheline-syenites and carbonatites, as well as their associated dykes and volcanic equivalents.

Therefore, this episode would include the A1 (pyroxenites and syenites with reported ages of 63-64 $\mathrm{Ma}$ ) and A2 (carbonatites and syenites) groups of Balogh et al. (1999), as well as the two groups established by Le Bas et al. (1986): Oligocene, Esquinzo ijolites/carbonatites and dPaleoceneT Ajui-Solapa ijolites/carbonatites and early pyroxenites and syenites.

Finally, it must be pointed out that the proposal of Cretaceous intrusive events in the Basal Complex of Fuerteventura has an important bearing on the interpretation of the evolution of the island. Thus, if we accepted an onset of the intrusive activity by Cretaceous-early Tertiary times, then the growth of the island, would have been exceptionally slow. In turn, if we consider that this activity started during the Oligocene, the development of the island, although still slow for an intraplate oceanic hot spot magmatism, is reduced to a significantly shorter lapse of time, which we consider more plausible. Additionally, both the Montañ a Blanca-Esquinzo and Ajui-Solapa areas make up a practically continuous outcrop, exclusively restricted to the western part of the island of Fuerteventura, and clearly controlled by a regional, NE-SW tectonic lineament, as has been proposed by several authors (Robertson and Stillman, 1979; Muñoz et al., 1997) and therefore, in such a context, a magmatic history involving two different episodes of alkaline magmatism, separated more than $30 \mathrm{Ma}$ in time, does not seem plausible.

\section{Conclusions}

Most of the previously published, $\mathrm{K}-\mathrm{Ar}$ and $\mathrm{Ar} / \mathrm{Ar}$ ages on the alkaline silicate rocks and carbonatites 
forming the first intrusive event (EM1) of the Basal Complex in Fuerteventura cluster around $25 \mathrm{Ma}$. This age has been corroborated by U-Pb, LA-ICP-MS dating of zircons from a nepheline-syenite at Caleta de la Cruz, where two sets of ages had been reported for nepheline-syenites: 63-64 and 23-25 Ma (Balogh et al., 1999). Field relationships of the alkaline silicate rocks and carbonatites, both in the northwestern, Montaña Blanca-Esquinzo and central-western, AjuiSolapa sectors in the island indicate, that the alkaline pyroxenites and melteigites-ijolites of this association are early cumulates, whereas nepheline-syenites and carbonatites represent differentiated melts pervading them. Our K-Ar data on pyroxenites from Caleta de la Cruz yield ages of 26-24 Ma, that strongly support the contemporaneity between them and syenites/carbonatites, discarding the suggestion that they could belong to an older, Cretaceous, either pyroxeniticgabbroic-syenitic event, as proposed by Le Bas et al. (1986) or ultramafic-syenitic event, as proposed by Balogh et al. (1999). Therefore, we propose a single alkaline-carbonatitic episode for the Basal Complex of Fuerteventura, taking place in the Oligocene (25 Ma).

\section{Acknowledgements}

The Electron Microscopy and Mineral Analysis Division (NHM, London) are kindly acknowledged for technical and logistic support. Our special thanks to Tony Wighton for his masterful polishing and good humour. We are also grateful to the Laboratorio de Geocronología y Geoquímica Isotópica and Centro de Microscopía Electrónica of the Complutense University (Madrid), especially to J. González del Tánago and A. Fernández-Larios. This work was supported by the PR1/03-11645 and BTE2003-0872 projects of the DGYCIT (Spain). This work greatly benefitted from reviews by $\mathrm{K}$. Bell and an anonymous referee.

\section{References}

Abdel-Monem, A., Watkins, N.D., Gast, P.W., 1971. Potassiumargon ages, volcanic stratigraphy, and geomagnetic polarity history of the Canary Islands: Lanzarote, Fuerteventura, Gran Canaria and La Gomera. American Journal of Science 271, 490-521.
Andersen, T., 2002. Correction of common lead in $\mathrm{U}-\mathrm{Pb}$ analyses that do not report $\mathrm{Pb}$. Chemical Geology 192, 59-79.

Balogh, K., Ahijado, A., Casillas, R., Fernández, C., 1999. Contributions to the chronology of the Basal Complex of Fuerteventura, Canary Islands. Journal of Volcanology and Geothermal Research 90, 81-101.

Cantagrel, J.M., Fú ster, J.M., Pin, C., Renaud, U., Ibarrola, E., 1993. Age Miocène inférieur des carbonatites de Fuerteventura (23 Ma: U-Pb zircon) et le magmatisme précoce d'une île océanique (Île Canaries). Comptes Rendues de l’Academie des Sciences Paris 316, 1147-1153.

Dalrymple, G.B., Moore, J.G., 1968. Argon 40: excess in submarine pillow basalts from Kilauea volcano, Hawaii. Science 161, 1132-1135.

Féraud, G., Giannérini, G., Campredon, R., Stillman, C.J., 1985. Geochronology of some Canarian dyke swarms: contribution to the volcano-tectonic evolution of the archipelago. Journal of Volcanology and Geothermal Research 25, 29-52.

Fernández, C., Casillas, R., Ahijado, A., Perelló, V., HernándezPacheco, A., 1997. Shear zones as a result of intraplate tectonics in oceanic crust: the example of the Basal Complex of Fuerteventura (Canary Islands). Journal of Structural Geology 19, 41-57.

Fú ster, J.M., Muñ oz, M., Sagredo, J., Yebenes, A., Bravo, T., Hernández Pacheco, A., 1980. Excursión 121 A+C del 268 I.G.C. a las Islas Canarias. Boletín Geoló gico y Minero de España 91 (II), 351-390.

Grunau, H.R., Lehner, P., Cleintaur, M.R., Allenback, P., Bakkar, G., 1975. New radiometric ages and seismic data from Fuerteventura (Canary Islands), Maio (Cape Verde Islands) and São Tomé (Gulf of Guinea). Progress in Geodynamics. Royal Society of the Netherlands Academy of Arts and Sciences, Amsterdam, pp. 90-108.

Harrison, T.M., McDougall, I., 1981. Excess ${ }^{40} \mathrm{Ar}$ in metamorphic rocks from Broken Hill, New South Wales: implications for ${ }^{40} \mathrm{Ar} /{ }^{39} \mathrm{Ar}$ age spectra and the thermal history of the region. Earth and Planetary Science Letters 55, 123-149.

Ibarrola, E., Fúster, J.M., Cantagrel, J.M., 1989. Edades K-Ar de las rocas volcánicas submarinas en el sector norte del Complejo Basal de Fuerteventura. ESF Meeting on Canarian volcanism Abstracts, 124-129.

de Ignacio, C., Muñoz, M., Sagredo, J., Barbero, L., 2002. Preliminary apatite-fission track geochronology of the Montaña Blanca-Milocho alkaline pluton (NW Fuerteventura, Canary Islands, Spain). Geotemas 4, 55-59.

Jackson, S.E., Pearson, N.J., Griffin, W.L., Belousova, E.A., 2004. The application of laser ablation-inductively coupled plasmamass spectrometry to in situ U-Pb zircon geochronology. Chemical Geology 211, 47-69.

Jeffries, T., Fernández-Suárez, J., Corfu, F., Gutiérrez-Alonso, G., 2003. Advances in $\mathrm{U}-\mathrm{Pb}$ geochronology using a frequency quintupled Nd:YAG based laser ablation system (lambda $=213$ $\mathrm{nm}$ ) and quadrupole based ICP-MS. Journal of Analytical Atomic Spectrometry 18, 847-855.

Le Bas, M.J., Rex, D.C., Stillman, C.J., 1986. The early magmatic chronology of Fuerteventura, Canary Islands. Geological Magazine 123, 287-298. 
Ludwig, K.R., 1998. On the treatment of concordant uranium-lead ages. Geochimica et Cosmochimica Acta 62, 665-676.

Ludwig, K.R., 2003. Isoplot 3.00. A geochronological toolkit for Microsoft Excel. Berkeley Geochronology Center Special Publication, 4 (70 pp.).

Muñoz, M., Sagredo, J., 1994. Reajustes mineraló gicos y geoquímicos producidos durante el metamorfismo de contacto de diques basálticos (Fuerteventura, Islas Canarias). Revista de la Sociedad Española de Mineralogía 17, 86-87.

Muñ oz, M., Sagredo, J., Rincó n-Calero, P.J., Vegas, R., 1997. Emplazamiento en una zona de cizalla dúctil-frágil transtensiva para el plutón de Pájara, Fuerteventura, Islas Canarias. Geogaceta $21,171-174$.

Muñoz, M., Sagredo, J., de Ignacio, C., 2002. Existencia de diques y tobas volcánicas relacionadas con la asociación alcalinocarbonatítica de Fuerteventura (Islas Canarias). Geogaceta 32, 63-66.

Muñ oz, M., Sagredo, J., de Ignacio, C., 2003. Fieldtrip guide: Fuerteventura. IV EuroCarb workshop, Canary Islands, Spain. 83 pp.

Robertson, A.H.F., Stillman, C.J., 1979. Submarine volcanic and associated sedimentary rocks of the Fuerteventura Basal Complex, Canary Islands. Geological Magazine 116, 203-214.
Rona, P.A., Nalwalk, A.J., 1970. Post-early Pliocene unconformity on Fuerteventura, Canary Islands. Geological Society of America Bulletin 81, 2117-2122.

Sagredo, J., Muñoz, M., Galindo, C., 1996. Características petrológicas y edad $\mathrm{K}-\mathrm{Ar}$ de las sienitas nefelínicas del Morro del Recogedero (Fuerteventura, Islas Canarias). Geogaceta 20, 506-509.

Schärer, U., 1984. The effect of initial ${ }^{230} \mathrm{Th}$ disequilibrium on young U-Pb ages: the Makalu case, Himalaya. Earth and Planetary Science Letters 67, 191-204.

Stacey, J.S., Kramers, J.D., 1975. Approximation of terrestrial lead isotope evolution by a two stage model. Earth and Planetary Science Letters 26, 207-221.

Wiedenbeck, M., Allé, P., Corfu, F., Griffin, W.L., Meier, M., Orbeli, F., von Quadt, A., Roddick, J.C., Spiegel, W., 1995. Three natural zircon standards for U-Th-Pb, LuHf, trace element and REE analyses. Geostandards Newsletter 19, 1-23.

Zeck, H.P., Whitehouse, M.J., 1999. Hercynian, Pan-African, Proterozoic and Archean ion-microprobe zircon ages for a Betic-Rif core complex, Alpine belt, W. Mediterranean; consequences for its P-T-t path. Contributions to Mineralogy and Petrology 134, 134-149. 